САША МИХАЈЛОВ и БИЉАНА МИШИЋ

Завод за заштиту споменика културе града

Београда, Београд

DOI 10.5937/kultura1754056M

УДК 721.171(497.11)(091)

оригиналан научни рад

ABOPCKИ KOMПNEKC

HA TEPA3ИJAMA:

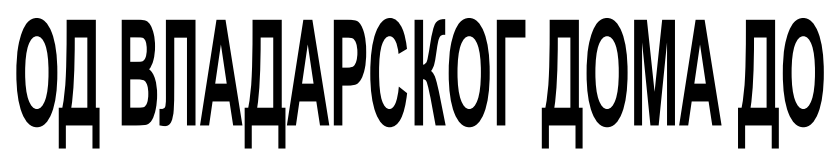

PEDPEЗEHTATИBHOГ

JABHOГ ПРОСТОРА

\begin{abstract}
Сажетак: Дворски комплекс на Теразијама, један од највреднијих амбијената историјског језгра Београда, формиран је у размаку од средине деветнаестог до почетка треће деиеније двадесетог века. Етапност у обликоваюу комплекса, осим што је потврдила доследност са идејама оригиналног пројекта из 1881, показатељ је и сложеног прочеса у којем су се преплитале уметничке и политичке кониепчије. Намера рада је да анализом фаза настанка комплекса расветли кључне чињенице његовог архитектонскоурбанистичког и пејзажног уређења, који са собом носе и важне симболичне, друштвене и политичке конотаиије. Промене које ће обележити развој комплекса у периоду након Другог светског рата у циљу његовог претварања у репрезентативни јавни амбијент и управно средиште Народне Републике Србије и ФНР / СФР Југославије, разматране су у контексту измењених друштвено-политичких услова. Акиенат рада је на утврђивағу удела које је формирање дворског комплекса на Теразијама имало у креирању топографије јавних простора централне градске зоне Београда у иирем историјско-друштвеном оквиру век и по уназад.
\end{abstract}

Кључне речи: Теразије, двор, дворска башта, Музеј кнеза Павла, државно-управно седиште, јавни парк 


\section{САША МИХАЈЛОВ и БИЉАНА МИШИЋ}

Дворски комплекс на Теразијама најзначајнији је микроамбијент централне градске зоне из којег је започето претварање оријенталног Београда у савремену престоницу нововековне српске државе. Насупрот европским дворовима који су настајали на местима ранијих резиденцијалних целина, формирање београдског дворског комплекса је, због специфичних историјских и политичких околности, започето средином деветнаестог века на локацији независној од некадашњег дворског и управног центра у Савамали. Неоптерећена прошлошћу ова позиција давала је могућност слободнијег обликовања дворске целине, али је истовремено подстакла и најавила убрзано ширење града и његово претварање у модерну европску метрополу.

\section{Симићево здање - нуклеус будућег дворског комплекса}

Само десетак година пре подизања Симићевог здања (18401842) неко ко би случајно прошао београдским Теразијама не би могао ни да замисли да ће на месту мочваре обрасле трском коју су настањивале бројне барске птице, изнићи будући управни центар Кнежевине Србије. Читав простор на којем се данас налазе Пионирски и Девојачки парк купио је Стојан Симић, једна од најутицајнијих личности Србије тог доба. Исушивањем и насипањем земљишта створени су услови за подизање прве репрезентативне грађевине на Теразијама, коју је Симић већ 1843. године продао држави за двор новог српског кнеза Александра Карађорђевића. ${ }^{1}$ Потреба за личном безбедношћу владара приморала је српске власти да за кнежев дом одаберу здање које је било довољно удаљено од седишта турских власти на Беогадској тврђави, али и од топчидерских поседа Обреновића и дворских објеката које је Милош тамо подигао крајем четврте деценије деветнаестог века. Претварањем Симићевог здања у кнежевски двор, ${ }^{2}$ касније називан Старим конаком, започето је формирање дворског комплекса. Здање наглашене

1 АС, Државни савет, 1844-195, према: Несторовић, Б. (2006) Архитектура Србије у XIX веку, Београд: Арт Прес, стр. 173-174. Детаљније о Симићевом здању видети: Ђурић-Замоло, Д. (1991) Стари конак у Београду, Годишьак града Београда бр. 38, Београд: Музеј града Београда, стр. 113-125; Митровић, К. Двор кнеза Александра Карађорђевића, у: Приватни живот код Срба у деветнаестом веку, уредили Столић, А. и Макуљевић, Н. (2006), Београд: Clio, стр. 302-330; Борић, Т. И. (2014) Дворови династија Обреновић и Карађорђевић у Србији, докторска дисертација, Филозофски факултет, Универзитет у Београду, Београд, стр. 121-137, 161-165.

2 Симићево здање је за потребе двора знатно проширено доградњом два бочна корпуса којима је готово удвостручена основа објекта. ЂурићЗамоло, Д. нав. дело, стр. 116. 
подужне основе због пада терена са улице се сагледавало као спратна, а са дворишне стране као приземна грађевина. Његова богато декорисана улична фасада са истакнутим бочним и улазним ризалитима надвишеним атиком са грбом Кнежевине Србије обликована је у духу неоренесансне архитектуре са примесама барокних елемената. Стари конак је у наредних шездесет година, када су у њему боравили кнежеви Александар Карађорђевић и Михаило Обреновић и потом краљеви Милан и Александар Обреновић, био место најзначајнијих догађаја српске државе и њених владарских династија.

Паралелно са преуређењем конака започето је формирање дворске целине изградњом приземне куће полукружне основе са топовима и кулом са сатом, која је служила за смештај страже кнежевске гарде, специјалних објеката за кухињу, кнежеву канцеларију и коњаничку гардијску касарну, као и култивисањем дворске баште коју је од улице делила гвоздена ограда са каменим стубовима и соклом. ${ }^{3}$ Захваљујући труду и истанчаном укусу кнегиње Персиде Карађорђевић башта је убрзо претворена у репрезентативно уређен „вернакуларни врт”, о којем је, судећи према архивским изворима, бригу водио професионални баштован. Убрзо, око 1845. године, са леве стране Старог конака подигнут је Мали дворац, класицистички обликована грађевина са наглашеним централним ризалитом надвишеним троугаоним фронтоном са хералдичким мотивом. ${ }^{4}$ Уређивање дворског комплекса и претварање овог амбијента у најрепрезентативнији простор који је Србија тада имала иницирало је ширење града у правцу некадашњег Крагујевачког друма. Средином деветнаестог века читаву ову зону карактерисала је ортогонална матрица са дијагоналном комуникацијом која спаја данашње тргове Теразије и Славију, ${ }^{5}$ уз коју су временом поодизани све значајнији и раскошнији објекти, мењајући физичку структуру и атмосферу простора и претварајући улицу Краља Милана у главну градску осу.

3 У оквиру дворског комплекса подигнут је и низ помоћних објеката међу којима и ледерница и неколико шупа; Исто, стр. 122-123.

4 Громанов албум фотографија 1876-1878, приредио Мијајловић, Ж. (2003) Београд, стр. 38, 8. 2. 2016., http://www.ncd.matf.bg.ac.rs/projects/ sr/groman.html; Маневић, 3. (2002-2003) Класицизам у српској архитектури, Зборник Матиие српске за класичне студије бр. 4-5, Нови Сад: Матица Српска, стр. 123-127; Кадијевић, А. (2009) Поглед на класицизам у новијој српској архитектури, Рачански зборник бр. 14, Бајина Башта: Фондација Рачанска баштина, Манастир Рача, стр. 115-122.

5 Dokumentacija ZZSKGB, Konzervatorski uslovi za rekonstrukciju zaštićene zone Andrićevog venca, KU 16; Марловић, С. (2005) Трагање за изгубљеном целовитошћу дворског комплекса у Београду, Годишњак града Београда бр. 52, Београд: Музеј града Београда, стр. 198-201. 
Значајније промене у оквиру комплекса десиле су се током друге половине деветнаестог века, по повратку династије Обреновић на српски владарски престо 1859. године. Иако је остарели кнез Милош одабрао да борави у свом топчидерском конаку, а кнез Михаило у Малом дворцу, Симићево здање је и даље било званична кнежевска резиденција. Уз њега је као пандан Малом дворцу, са десне стране започета изградња двора Престолонаследника Михаила (1858). Оваквим позиционирањем објекта уочава се тежња да се целина дворског комплекса организује као трочлана композиција (слика 1). Конципирана у виду једноспратне грађевине разуђене симетричне основе, чија је главна улична фасада носила све одлике романтичарске архитектуре средњоевропског порекла, ова зграда је, уз истовремено грађено Капетан Мишино здање, била најрепрезентативнија грађевина тог доба у Београду и један од најлепших примера архитектуре романтизма у Србији. Планове по којима је реализована израдили су водећи архитекти Главне управе грађевина Јован Френцл и Јосиф Касано, док је архитекта Коста Шрепловић, који је дуго сматран аутором објекта, највероватније вршио надзор при завршној фази радова. ${ }^{6}$ Изградња овог објекта утицала је на начин уређења читавог околног простора, чији су тада формирани блокови сачувани у неизмењеном облику до данас. По завршетку градње, уместо кнеза Михаила који се уселио у Стари конак, у ново здање је усељено Министарство иностраних и унутрашњих послова, које се овде налазило све до 1911. године.

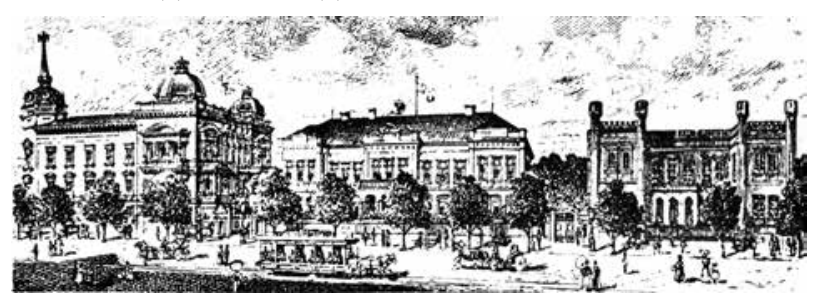

Слика 1 Изглед дворског комплекса крајем 19. века (Феликс Каниц, Србија, земьа и становништво)

Пуну пажњу уздизању угледа двора и његове улоге у репрезентацији владара, династије и монархије посветио је кнез Михаило Обреновић током своје друге владавине. Простор, око дворских објеката је подељен на врт, репрезентативни сегмент полујавног карактера у предњем делу, и парк у виду слободније уређене баште у задњем делу комплекса. Врт је структурисан по принципима геометризованог француског формализма и ограђен према улици металном оградом са позлаћеним шипкама. Уређењу парка и његовом

6 Несторовић, Б. нав. дело, стр. 182; Борић, Т. И. нав. дело, стр. 151. 


\section{САША МИХАЈЛОВ и БИЉАНА МИШИЋ}

симболичном тумачењу посвећивано је више пажње, а сам простор је постепено добио интимнији карактер, намењен шетњи и одмору владарске породице. У његовом средишту изграђен је базен са каменим узвишењем на којем је постављена бронзана скулптура девојке са крчагом у руци импортована из Беча, једна од најлепших уметничких скулптура Београда тог времена.

Ситуација читавог дворског комплекса у њеном данашњем изгледу, са јасно дефинисаном границом блока, парцелацијом и основама постојећих објеката први пут је приказана на Зарићевом плану из 1878. године. У позадини Старог конака уцртана је зграда страже, у предњем делу уређен врт, док се иза Малог дворца уочавају контуре штала за коње и магацина. На простору који обухватају улица Кнеза Милоша и Крунска налазила се група објеката, међу којима и једноспратна грађевина обележена као Министарство војске, које се у овом објекту налазило до пресељења у нову зграду на углу Немањине и улице Кнеза Милоша. ${ }^{7}$ Простор према данашњем Булевару кнеза Александра означен је као башта. На плану се јасно истичу основе све три првобитне репрезентативне грађевине комплекса: Стари конак, Мали дворац и Министарство иностраних и унутрашњих послова, чијим се међусобним односом јасно уочава трочлана композиција целине, што ће убрзо постати кључна идеја новог пројекта краљевског двора.

\section{Стари и Нови двор - краљевске палате}

Идеја о претварању дворског комплекса у репрезентативну резиденцијалну целину подизањем Новог владарског дома јавила се у време стицања државне самосталности и територијалног проширења Србије после Берлинског конгреса 1878 , а додатно је подстакнута припремама за проглашење Србије за краљевину неколико година касније. ${ }^{8}$ Пројекат новог владарског двора архитекте Александра Бугарског (1835-1891), једног од најзначајнијих српских градитеља друге половине деветнаестог века, заснован је на трипартитној репрезентативној структури, осмишљеној са намером да превазиђе све до тада званичне резиденције српских владара. Концепција комплекса дефинисана је по узору на средњоевропске дворске палате које је архитекта имао прилику да види и упозна током студирања и рада у Пешти и

\footnotetext{
7 Ђурић-Замоло, Д. нав. дело, стр. 124.

8 Мишић, Б. (2005) Ефемерни спектакл - проглашење Србије за краљевину 1882. године, Наслеђе бр. 6, Београд: ЗЗСКГБ, стр. 86-87.
} 


\section{САША МИХАЈЛОВ и БИЉАНА МИШИЋ}

Мађарској, ${ }^{9}$ али и под утицајем италијанске класичне архитектуре чије је постулате применио и на претходном значајном пројекту у Београду - згради Народног позоришта (1867-1869). Према овој замисли, ${ }^{10}$ у којој је удео имао и лични афинитет и укус краља Милана Обреновића, комплекс би чинили централно постављен краљев двор, двор престолонаследника са југоисточне (десне) стране и објекат протоколарне намене на северозападној (левој) страни композиције. Предвиђено је и формирање проспекта у виду терасе на месту данашњег Девојачког парка, који би обезбедио квалитетно сагледавање целине, док би се из двора пружале широке визуре на делове града према реци Сави. Међутим, како се често дешавало у српској прошлости, историјски догађаји предухитрили су архитектонске подухвате. Од целокупне амбициозно замишљене концепције Бугарског реализовано је само лево крило комплекса оригинално намењено јавним скуповима и дипломатским пријемима - данас познато као Стари двор. ${ }^{11}$

Репрезентативна академски обликована грађевина изграђена 1881-1884. ${ }^{12}$ на месту некадашњег Малог дворца, да би се разликовала од суседног Старог конака, добила је назив

9 Покрајац, М. (2013) Александар Бугарски: пионир академизма у Београду, Годишьак града Београда бр. 60, Београд: Музеј града Београда, стр. 74-75.

10 Како оригинални планови архитекте Бугарског нису сачувани, о новим плановима и идејама сазнајемо искључиво на основу записа савременика и оновремене штампе. Каниц, Ф. (1985) Србија, земља и становништво: од римског доба до краја ХІХ века, књига 1, Београд: Српска књижевна задруга, стр. 71; Nikić, Lj. (1978) Iz arhitektonske delatnosti Aleksandra Bugarskog u Beogradu, u: Urbanizam Beograda br. 46, Beograd: Urbanistički zavod, str. 64.

11 За пројекат по којем је реализовано ово здање архитекта Бугарски награђен је 1889. орденом Светог Саве. Нису познати разлози због којих његова оригинална замисао није реализована. Податак који наводе Каниц и Стојановић да је изградњу Старог двора довршио архитекта Јован Илкић неки историографи доводе у питање због чињенице да је Бугарски све до 1890. био ангажован у служби Министарства грађевина. Стојановић, С. (1912) Српски неимар, Београд, 1912, стр. 101-102; ЂурићЗамоло, Д. (2009) Градитељи Београда 1815-1914, Београд: Музеј града Београда, стр. 55; Недић, С. В. (1999) Из историје Старог двора, Наслеђе бр. 2, Београд: ЗЗСКГБ, стр. 11.

12 Autograf Aleksandra Bugarskog od 27. januara 1887. Arhiv SANU, sign. br. 7553. Према: Покрајац, М. нав. дело, стр. 93. Детаљније о Старом двору: Dokumentacija ZZSKGB, dosije spomenika kulture Zgrada Starog dvora, SK-159; Недић, С. В. нав. дело, стр. 11-22; Столић, А. Приватност у служби репрезентације - двор последњих Обреновића, у: Приватни живот код Срба у деветнаестом веку, уредили Столић, А. и Макуљевић, Н. (2006) Београд: Clio, стр. 331-353; Мишић, Б. (2013) Зграда Старог двора, Београд: ЗЗСКГБ; Борић, Т. И. нав. дело, стр. 173-188. 


\section{САША МИХАЈЛОВ и БИЉАНА МИШИЋ}

Нови двор. ${ }^{13}$ Грађен са намером да буде део троделне целине двор је добио специфичну оријентацију са главном фасадом према дворском врту без наглашеног репрезентативног приступа (слика 2). Њена складност остварена је уравнотеженим распоредом архитектонских елемената - балкона, стубова са јонским и коринтским капителима, паровима каријатида, декоративне фасадне пластике и двема куполама на угловима украшеним краљевским крунама. Сличну раскошност пратила је фасада према улици Краља Милана, чији је угаони део према улици Драгослава Јовановића обликован у виду осмостране куле са куполом коју краси високи шиљак са двоглавим орлом на врху. ${ }^{14}$ Постављање краљевског симбола на најистакнутијим деловима архитектонске композиције - врховима све три куполе, тимпанону спрата бочног ризалита фасаде према улици Краља Милана и фигурама грифона на главној фасади према башти, потврЂује директну везу између грађења двора и чина успостављања краљевине. ${ }^{15}$ Једноставније обрађеном фасадом према башти доминирао је бочни ризалит са тространом апсидом дворске капеле на спрату и једноставно обликован улаз под тремом. По свим својим обликовним карактеристикама, складним односом између симетричне форме и разуђених фасада са богатом декорацијом античког, ренесансног и барокног порекла, Стари двор у потпуности одражава стилске и архитектонске тенденције епохе којој припада. ${ }^{16} \mathrm{O}$ унутрашњем уређењу двора, опремљеном у бечким уметничким радионицама, бринула је комисија коју су поред архитекте Бугарског, чинили професор Велике школе Михаило Валтровић и декоративни сликар Доменико д’Андреа. ${ }^{17}$

13 Овај назив је био у употреби све до рушења Старог конака 1903. године. Стари двор се као назив усталио после завршетка изградње Новог двора 1914. и као такав се очувао до данас.

14 Аноним (5. VI 1883) Српско-краљевски орао на Краљевом двору, Buдело, стр. 3; Поповић, М. (1997) Хералдички симболи на београдским јавним здағима, Београд: БМГ, стр. 52.

15 Како је пројектовање двора започето 1881. првобитни хералдички програм фасада није обухватао краљевска знамења, већ су она накнадно придодата пројекту након проглашења Србије за Краљевину 22. фебруapa 1882 године. О хералдичким представама на фасадама Старог двора видети у: Поповић, М. нав. дело, стр. 52; Pokrajac, М. (2015) Heraldički dekor u službi vladarske ideologije na fasadama Starog dvora, Artum br. 2, Beograd: Odeljenje za istoriju umetnosti Filozofskog fakulteta u Beogradu, str. 52-61.

16 О слојевитости академски обликованих фасада Старог двора видети: Кадијевић, А. (2005) Естетика архитектуре академизма (XIX-XX века), Београд: Грађевинска књига, стр. 339-340.

17 Стојановић, С. нав. дело, стр. 21-22, 101-102; Недић, С. В. нав. дело, стр. $15,18$. 


\section{САША МИХАЈЛОВ и БИЉАНА МИШИЋ}

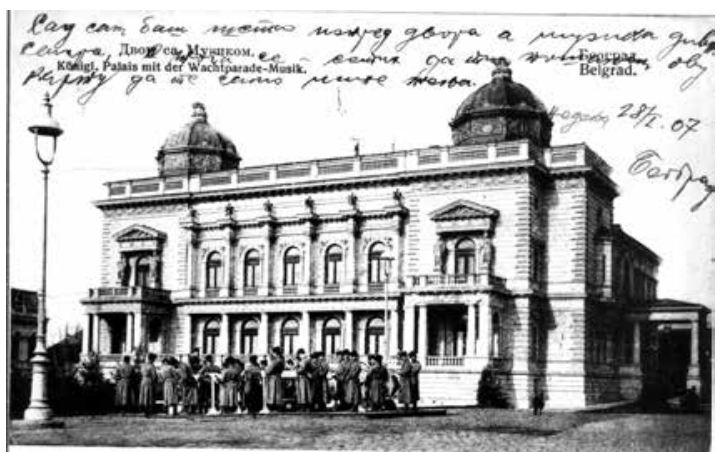

Слика 2 Александар Бугарски, Стари двор,

Главна фасада, почетак 20. века (Извор: ЗЗСКГБ)

У оквиру трансформације дворског комплекса за време династије Обреновић знатна пажња посвећена је артифицирању амбијента постављањем нове металне ограде са декоративно изведеним капијама према улици Краља Милана. С друге стране, приватни део комплекса са баштом био је ограђен зиданом оградом висине преко $3 \mathrm{~m}$, у оквиру које су се налазиле стражаре и улази из данашњих улица Драгослава Јовановића и Булевара краља Александра. Изгледу дворске баште и њеном претварању у дворски парк посебно је допринела традиција сађења ретких и племенитих стабала, карактеристична за европске дворове, као и лично залагање краља Милана, док је идеологија патриотизма подстицала избор садница карактеристичних за националну територију. Природни фонд парка обогаћен је младицама из Панчићеве ботаничке баште, али је његова специфичност остварена садњом врста карактеристичних за наше поднебље, међу којима посебно место има Таковски грм из времена кнеза Милоша, пренет 1900. у средиште дворског парка где се и данас налази. ${ }^{18}$

Нова етапа у развоју дворског комплекса наступила је са династичком променом на српском престолу. Дворски комплекс се нашао у средишту Мајског преврата 1903, догађаја који је читава Европа осудила као варварски и нецивилизацијски. Чин убиства краља Александра и краљице Драге Обреновић у Старом конаку запечатио је судбину овог здања које је порушено наредне године, ${ }^{19}$ али је означио и наставак ширења комплекса са циљем да се поврати пољуљани углед српске краљевине међу европским монархијама. Стари двор је прихваћен као званична резиденција династије

18 Тимотијевић, М. (2009) Престоничка урбана меморија и флексибилна национална географија: сађење младице Таковског грма у београдском дворском парку, Наслеђе бр. 10, Београд: ЗЗСКГБ, стр. 31.

19 Аноним (1. VIII 1904), Рушење Старог дворца, Политика, стр. 3. 


\section{САША МИХАЈЛОВ и БИЉАНА МИШИЋ}

Карађорђевић (1903-1914), али се веома рано показало да је неподесан за стални боравак краљевске породице и протоколарне свечаности, па се део дипломатских пријема одвијао у оближњој кући Алексе Крсмановића у улици Теразије број $34 .{ }^{20}$ Таква неадекватна ситуација за репрезентацију нове српске династије убрзала је припреме за подизање Новог двора.

Најранији материјални трагови о плановима да се подигне нова резиденција, који датирају из јула 1906, говоре о намери дворских власти да пројекат буде одабран на основу конкурса. ${ }^{21}$ Ипак, до расписивања јавног конкурса није дошло, а изградња је одложена до 1910. године када је за пројектанта именован Стојан Тителбах (1877-1916), архитекта Министарства грађевина. Програмски задатак обухватао је пројектовање двора за Александра Карађорђевића, који је годину дана раније проглашен за наследника престола. ${ }^{22} \mathrm{He}-$ реализовани део идејног пројекта Бугарског, стар више од две деценије, био је напуштен, али је задржана идеја о трочланој резиденцијалној целини. У тој одлуци, која је подразумевала да се дворски комплекс заокружи изградњом Новог двора на месту зграде Министарства спољних и унутрашњих послова могуће је прочитати потребу нове династије за остваривањем континуитета са владавином својих претходника из династије Обреновић. Помирљиво уверење да су обе српске нововековне династије подједнако допринеле стварању модерне српске државе овде је исказано архитектонским језиком.

Судбину Новог двора грађеног од 1911. до средине 1914. године, као и читаве државе, одредило је избијање Првог светског рата. Ратни вихор је грађевину оставио у рушеви-

20 Крсмановићева кућа на Теразијама имала је и касније значајну улогу у дворским и државним званичним свечаностима. Након Првог светског рата, због нефункционалности дворских зграда услед оштећења током ратних бомбардовања, у овој кући потписан је 1. децембра 1918. документ о формирању Краљевине Срба, Хрвата и Словенаца. Детаљније: Dokumentacija ZZSKGB, dosije spomenika kulture Krsmanovićeva kuća na Terazijama, SK-36; Димитријевић Марковић, С. (2012) Крсмановићева кућа на Теразијама, Београд: ЗЗСКГБ.

21 Аноним (11. VII 1906) Грађење новог дворца, Штампа; Аноним (24.VII 1906) Грађење новог дворца, Штампа.

22 Детаљније о Новом двору видети: Dokumentacija ZZSKGB, dosije spomenika kulture Zgrada Novog dvora, SK-160; Недић, С. В. (2001) О неким питањима изворне архитектуре Новог двора, Наслеђе бр. 3, Београд: 33СКГБ, стр. 57-66; Вујовић, С. Градско становање и приватност у Србији током 20. века, у: Приватан живот код Срба у двадесетом веку, уредио Ристовић, М. (2007), Београд: Clio, стр. 275-291; Михајлов, С. (2013) Зграда Новог двора, Београд: ЗЗСКГБ; Борић, Т. И. нав. дело, стр. 196-203. 


\section{САША МИХАЈЛОВ и БИЉАНА МИШИЋ}

нама, али су убрзо, време страдања и патњи заменили срећни догађаји који су подстакли обнову здања како би оно постало нови дом краљевског пара и седиште Маршалата. ${ }^{23}$ Све до 8. јуна 1922, када се у двор уселио краљ Александар I Карађорђевић на дан венчања са румунском принцезом Маријом, о његовом уређењу је бригу водила комисија коју су чинили сликар Урош Предић и архитекте Петар Поповић и Момир Коруновић, који је био и главни надзорник радова.

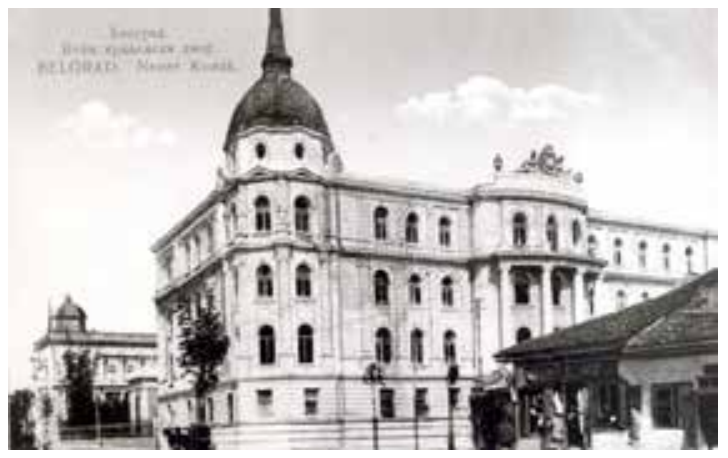

Слика 3 Стојан Тителбах, Нови двор, изглед након Првог светског рата (Извор: ЗЗСКГБ, Збирка Сергеја Димитријевића)

Замишљена као пандан здању Бугарског, архитектура Новог двора истицала је идеју историјског заокруживања дворског комплекса. То је темељно одредило архитектонски лик ове зграде, од њене опште оријентације до система рашчлањавања фасада и стилске обраде. Огледалском симетријом поновљени су елементи обликовања Старог двора: оријентација најрепрезентативније фасаде према врту, угаони ризалит у виду куле са куполом, доследно спроведен општи принцип симетрије у шеми организације основе и композицији академски обликованих фасада са стилским елементима преузетим из ренесансне и барокне архитектуре, као и истицање хералдичких симбола у оквиру декоративног програма спољашњости. Симетричност главне фасаде овог репрезентативног двоспратног здања постигнута је наглашавањем бочних и централног ризалита у чијем је средишту позициониран главни улаз са овалним тремом. Хералдички програм, исказан монументално обликованим потпуним грбом краљевске династије Карађорђевић у лунети средишњег ризалита, употпуњен је постављањем бронзане фигуре двоглавог орла у полету на најдоминантнијем делу здања - куполи са шиљком смештеној на споју фасада према

23 Маршалат је био смештен у десном крилу приземља. Игњатовић, А. Архитектура Новог двора и Музеја кнеза Павла, у: Музеј кнеза Павла, уредила Цветићанин, Т. (2009) Београд: Народни музеј, стр. 86. 


\section{САША МИХАЈЛОВ и БИЉАНА МИШИЋ}

улицама Краља Милана и Андрићев венац (слика 3). ${ }^{24}$ Овим решењем октогоналног угаоног сегмента, који одговара замишљеној оси симетрије целине, стављен је завршни акценат у визуелном и симболичком повезивању Старог и Новог двора у јединствен архитектонски ансамбл.

Други значајан елемент архитектуре Новог двора, у којем може да се препозна покушај симболичког указивања на конструисање демократског идентитета државе под династијом Карађорђевић, био је централни ризалит фасаде према улици Андрићев венац, решен у виду екседре обликоване као архитектонски цитат преузет са бочних фасада Дома Народне скупштине (1907-36) архитекте Јована Илкића. Овим градитељским поступком додатно је наглашена повезаност владарског дома и парламента, што је у пренесеном значењу требало да учврсти јединство нације и суверена. Оваква идеолошка мотивисаност архитектуре Новог двора, у знатно ширем друштвеном и културном контексту, добиће посебно место у пројектима преобликовања читаве целине у периоду након Другог светског рата.

Стари двор је страдао у бомбардовању 1914. и 1915. године али је делом обновљен од стране аустроугарских власти које су га користиле као седиште своје привремене управе Београдом. У свечаној Сали двора су се након Првог светског рата током 1919-1920. одржавале седнице привремене Народне скупштине. ${ }^{25}$ Рестаурацијом изведеном 1921. године под надзором комисије коју је предводио сликар Урош Предић, све просторије у приземљу добиле су своју првобитну намену и оригиналан изглед. Уређење је поверено двема иностраним фирмама - бечкој радионици Бернарда Лудвига (Bernhard Ludwig), која је опремала просторије у приземљу и париској кући Безије (Bézier) која је обликовала изглед просторија на спрату. Као и пре рата намештај је био у стилу француских Лујева и ренесансе, али се својим источњачким изгледом посебно издвајао округли салон у приземљу. Слично су биле опремљене и шездесетдве просторије Новог двора, чије је уређење извела кућа Безије у сарадњи са београдским уметничким столарима. Међу просторијама овог здања опремљеним у стилу Лујева и директоријум-намештаја издвајала се босанска соба, која је, уређена по угледу на ентеријере балканско-оријенталне архитектуре, сматрана најлепшим примером престоничке примењене уметности. ${ }^{26}$

24 Поповић, М. нав. дело, стр. 75-79, 138-139.

25 Аноним (6. V 1922), Стари двор, Политика, стр. 3-4.

26 Popović, B. (2011) Primenjena umetnost i Beograd 1918-1941, Beograd: Muzej primenjene umetnosti, str. 88-89, 95; О архитектури босанске собе погледати и: Ignjatović, А. (2007) Jugoslovenstvo u arhitekturi 1904-1941, 


\section{САША МИХАЈЛОВ и БИЉАНА МИШИЋ}

Репрезентативне дворске просторије су, дакле, осим о утицају средњоевропских ентеријера у нашој средини током међуратног периода, јасно указивале на моду „босанских соба”, на коју су се угледали многи имућнији Београђани.

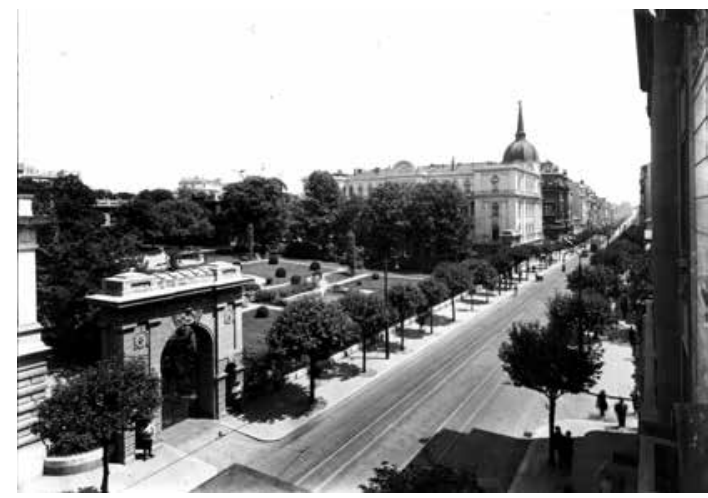

Слика 4 Дворски врт и део амбијента улице Краља Милана, 1930-1935. година (Извор: Колекција Милоша Јуришића)

Истовремено са обновом Старог и подизањем Новог двора током 1919-1920. архитекта Момир Коруновић спровео је темељно преобликовање и доградњу „потковичасте” зграде дворске страже, чији је положај након рушења Старог конака постао пресудан у повезивању дворских објеката. Ово некада ненаметљиво здање сада је препројектовано у двоспратну структуру са нижим полукружно извијеним крилима, у потпуности подређену архитектонском стилу и урбанистичкој позицији дворова. На крајевима бочних крила, као пандан централном ризалиту главне фасаде Новог двора, изведени су лучни забати украшени хералдичким знамењем Краљевине СXC. ${ }^{27}$ Уз Нови двор према улици Андрићев венац налазила се шумадијска кућица у коју је смештена доврска кухиња, функционално повезана подземним ходником са сутереном двора. ${ }^{28}$ Ограда између дворова добила је репрезентативан изглед са тријумфално обликованим капијама богато украшеним пластичном декорацијом и стражарским местима према улици (слика 4). Осим што је доприносила повезивању дворских објеката, ограда је употпунила изглед знатно проширеног дворског врта, који је добио дефинисанији изглед преобликовањем зграде страже у његовом залеђу и новим геометријским партерним уређењем са

Beograd: Građevinska knjiga, str. 246; Путник, В. (2012) Прилог проучавању развојних токова међуратне стамбене архитектуре Београда, Наслеђе бр. 13, Београд: ЗЗСКГБ, стр. 159.

27 Кадијевић, А. (1996) Момир Коруновић, Београд: Републички завод за заштиту споменика културе, стр. 41-43.

28 Недић, С. О неким питањима, стр. 59. 


\section{САША МИХАЈЛОВ и БИЉАНА МИШИЋ}

фонтаном у средишту. Овим поступком још је наглашеније исказана ранија подела дворског комплекса на врт и парк, односно на јавни и приватни део комплекса (слика 5).

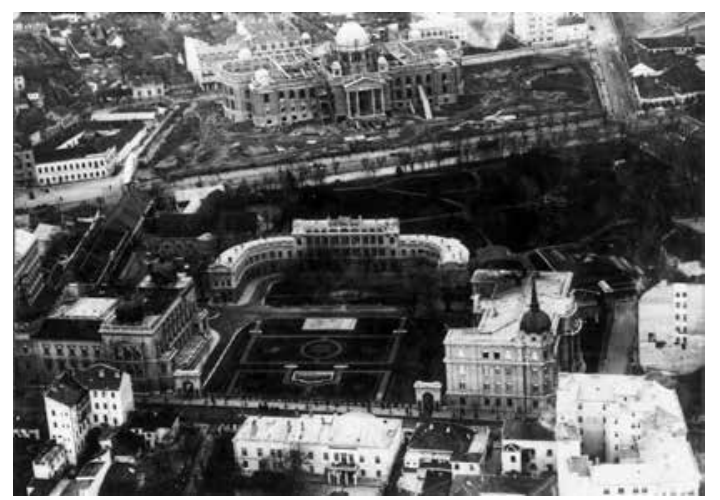

Слика 5 Дворски комплекс на Теразијама и Дом Народне скупштине у изградњи, авиоснимак, око 1925. године

(Извор: Музеј ваздухопловства)

Стари двор је током готово читавог међуратног периода служио својој оригиналној намени - дворским скуповима и пријему високих страних гостију. Темељна обнова здања уследила је 1930-1931. под надзором архитекте Управе двора Драгомира Тадића, којом су све фасаде и декоративна пластика, првобитно изведени у малтеру, замењени ликорезачким и украсним радовима у вештачком камену по замисли архитекте Светомира Лазића. ${ }^{29}$ Нови двор је као званична владарска резиденција служио све до пресељења краљевске породице у новоизграђени дедињски комплекс 1934, када је по жељи самог краља Александра уступљен за Краљевски музеј, убрзо преименован у Музеј кнеза Павла. ${ }^{30}$ Адаптацијом спроведеном 1934-35, која је обухватала побољшање функционалности ентеријера, његове осветљености и комуникације кроз поставку, руководила је комисија коју су чинили директор музеја Милан Кашанин и архитекте Иван Здравковић и Драгиша Брашован. Модерним уређењем грађевине, чије опремање је извео архитекта Милан Секулић, створени су услови за рад савремене музејске институције чије је свечано отварање уприличено 18. јануара 1936. године. С друге стране, сама поставка коју су чинили предмети из праисторије, антике и средњег века, као и из националне историје, југословенске уметности 19. века и савремене европске уметности, обезбедили су музеју

29 Дамљановић, Т. (1997) Архитекта Светомир Лазић (1894-1985), Caоnштеља бр. 29, Београд: Републички завод за заштиту споменика културе, стр. 250.

30 О преуређењу Новог двора за потребе савремене музејске институције видети: Игњатовић, А. нав. дело, стр. 58-89. 
статус најзначајније установе културе у Краљевини и једне од најсавременијих у европским оквирима. ${ }^{31}$ Осим еманципаторске, естетске и просветитељске улоге коју је по својој суштини носила институција музеја, Музеј кнеза Павла био је конкретан израз припадности европском културном и уметничком миљеу.

Већ средином двадесетих година када су оба дворска објекта реконструисана и изграђена, постало је јасно да они неће бити дом краљевске породице, за коју је већ почело зидање нове званичне породичне резиденције на Дедињу. Теразијски дворски комплекс требало је да преузме јавну функцију краљевске канцеларије, што је већ тада најавило правац промена у којем ће се одвијати развој овог простора у наредном периоду. Пренаменом и претварањем Новог двора у музејски и репрезентативни јавни простор остварено је својеврсно симболичко преклапање којим је исказана идеја културне, друштвене и политичке кохеренције, али је истовремено антиципирано и свеобухватно преиначавање теразијског комплекса деценију касније, у новим друштвенополитичким условима.

\section{Краљевски дворови - седишта нових сочијалистичких власти}

Стари двор је значајно оштећен током шестоаприлског бомбардовања Београда 1941, док је Нови двор захваљујући знатно мањем страдању, убрзо обновљен и оспособљен за наставак рада музеја. ${ }^{32}$ Међутим, након ослобођења 1944. нова држава и нова власт имали су другачије планове у вези са будућом наменом дворских објеката. Реконструкција која је уследила 1947-48. заснивала се на ширем захвату претварања некадашњег дворског комплекса у управно средиште Народне републике Србије и новоформиране југословенске државе. Стари двор је претворен у седиште Президијума

31 О активностима Музеја кнеза Павла погледати: У. (1937) Музеј кнеза Павла: Изложба пољске уметности - откопавања у Стобима", Уметнички преглед бр. 2, стр. 62; М. К. (1937) Женски портрет, од Тулуз-Лотрека, Уметнички преглед бр. 3, стр. 95; Васић, П. (1938) Никола Пусен код нас, Уметнички преглед бр. 5, стр. 129-134; П. В. (1938) Изложба италијанског портрета, Уметнички преглед бр. 6-7, стр. 221-223; Аноним (1939) Француска изложба у Музеју кнеза Павла, Уметнички преглед бр. 2, стр. 63; Аноним (1939) Музеј кнеза Павла - Изложба немачких слика, Уметнички преглед бр. 10, стр. 319; У. (1940) Валонска дворана у Музеју кнеза Павла, Уметнички преглед бр. 1-2, стр. 61.

32 Музеј кнеза Павла радио је у Новом двору са неколико прекида током периода 1936-1948. У децембру 1944. за директора је постављен Вељко Петровић, а Музеј је поново отворен 8. фебруара 1946. године под именом Уметнички музеј. 


\section{САША МИХАЈЛОВ и БИЉАНА МИШИЋ}

скупштине ФНРЈ, добивши потпуно нови изглед и просторни распоред. ${ }^{33}$ Као што је некад краљ Милан учествовао у обликовању замисли свог двора, тако је сада председник Президијума Моша Пијаде предложио измене које су архитектонски обликовали архитекте Александар Ђорђевић, Драгиша Брашован и Милан Минић. ${ }^{34}$ Према Брашовановом решењу Стари двор добио је ново прочеље са североисточне стране, употпуњено репрезентативним прилазом и уређеним партером на простору некадашњих помоћних дворских зграда (слика 6). Суштинско идеолошко преиначавање остварено је уклањањем краљевских симбола из програма вајаног украса на фасадама здања, двоглавог орла на великој куполи и две мање куполе са краљевским крунама, и местом новог државног знамења. Обрада ентеријера изведена је на знатно скромнији начин, који се као такав уз незнатне измене задржао до данас.

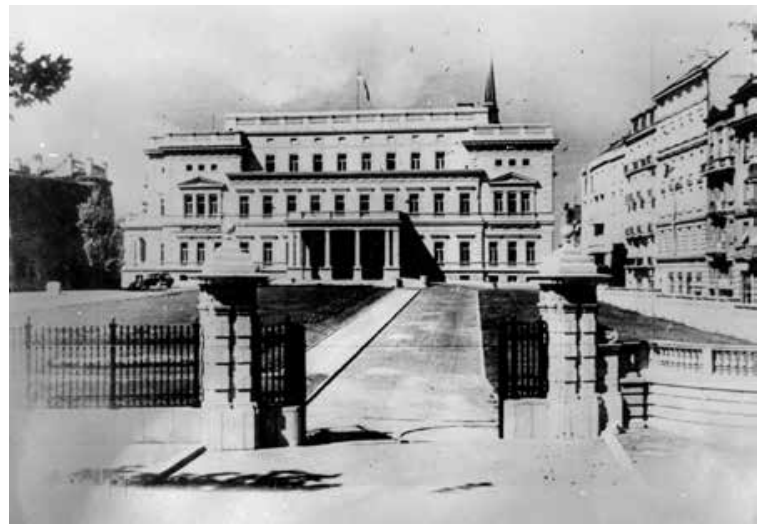

Слика 6 Драгиша Брашован, Стари двор, изглед главне фасаде након реконструкције 1948, фотографија око 1950. године

(Извор: ЗЗСКГБ)

33 Осим Президијума Народне скупштине, у Старом двору се након Другог светског рата налазило и седиште Владе ФНРЈ, Савезно извршно веће, а од 1961. до данас у њему је смештена Скупштина града Београда.

34 Dokumentacija ZZSKGB, dosije spomenika kulture Zgrada Starog dvora, SK-159; Кадијевић, А. (1990) Живот и дело архитекте Драгише Брашована 1887-1965, Годишњак града Београда бр. 37, Београд: Музеј града Београда, стр. 165, Кадијевић, А. (1996) Београдски опус архитекте Милана Минића (1889-1961), Годишњак града Београда бр. 43, Београд: Музеј града Београда, стр. 145; Михајлов, С. (2000-2001) Прилог проучавању архитектонског дела Милана Минића у Београду, Годишњак града Београда бр. 47-48, Београд: Музеј града Београда, стр. 235; Кадијевић, А. и Марковић, С. (2003) Милан Минић: архитект и сликар, Пријепоље: Музеј, стр. 84. 


\section{САША МИХАЈЛОВ и БИЉАНА МИШИЋ}

Реконструкција Новог двора за потребе председништва Владе НР Србије ${ }^{35}$ изведена је 1948-52. према пројекту архитекте Милана Минића, ${ }^{36}$ којим је извршено знатно проширење објекта у делу према Старом двору, доградњом велике свечане сале са приступним вестибилом, као и потпуно ремоделовање главне фасаде, која је добила ново архитектонско решење са карактеристичном колонадом јонских стубова. У складу са изменама на Старом двору, нови прилаз згради Новог двора обликован је на североисточној страни према данашњем Пионирском парку. Краљевска знамења замењена су амблемима новог државног уређења, од којих се посебно издваја хералдичка композиција над новим главним порталом. У унутрашњем уређењу посебна пажња посвећена је уређењу вестибила који је украшен делима Томе Росандића - двема алегоријским рељефним композицијама у нишама и композицијом у високом рељефу која приказује обнову и изградњу земље. Свечана сала украшена је монументалним композицијама Косовски бој Петра Лубарде и 27. март 1941. Мила Милуновића, изведеним у форми триптиха.

Уз реконструкцију и пренамену репрезентативних краљевских резиденција, послератна обнова обухватила је и претварање дворске баште у јавни парк са циљем да се читав простор некадашњег дворског комплекса визуелно и функционално повеже са оближњим монументалним здањем Народне скупштине. Прва идеја о преуређењу овог простора забележена је у напису архитекте Николе Добровића из $1946,{ }^{37}$ који се залагао за повезивање улице Краља Милана и Булевара краља Александра и формирање пешачке комуникације која би знатно допринела сагледивости и приступачности читавог комплекса. Генералним планом Београда из 1950. године ова идеја је разрађена формирањем манифестационог трга између Дечанске улице и Булевара краља Александра, која ће потом бити формално и просторно дефинисана изградњом Дома Синдиката (1947-55). Истовремено са уређењем трга започето је рушење блока зграда на углу са Влајковићевом улицом, уклањање ограда око Народне

35 Осим Председништва Владе НРС у Новом двору се након Другог светског рата налазило и Извршно веће НРС, Скупштина НРС, Председништво СРС, као и седиште Председника Србије, које је у њему до данас.

36 Dokumentacija ZZSKGB, dosije spomenika kulture Zgrada Novog dvora, SK-160; Кадијевић, А. Београдски опус архитекте Милана Минића (1889-1961), стр. 145; Михајлов, С. Прилог проучавању архитектонског дела Милана Минића у Београду, стр. 235; Кадијевић, А. и Марковић, С. нав. дело, стр. 84

37 Добровић, Н. (1947) Обнова и изградња Београда - Контуре будућег града, Београд: Урбанистички институт, стр. 12. 
скупштине и дворске баште, као и претварање баште у јавни парк резиденцијалног типа. Са циљем бољег визуелног повезивања теразијских објеката и Дома народне скупштине, уз образложење „стилске и композиционе неусклађености“ са преосталим делом комплекса, 1953. је уклоњен и последњи објекат некадашње дворске баште - зграда страже, у коjoj се од завршетка рата налазио Етнографски музеј..$^{38}$ Овим захватом остварени су сви услови за обликовање јединственог градског зеленог простора, Пионирског парка.

Преуређење дворске баште у парк је започето према пројекту архитекте Александра Ђорђевића, који је делом реализован, а потом настављено према решењу инжењера шумарства Владете Ђорђевића и пројекту партерног уређења према улици Краља Милана архитекте Николе Гавриловића. Парк је 1975-76. проширен пјацетом у виду пешачке комуникације са каскадном фонтаном дуж улице Андрићев венац, реализованом према пројекту архитекте Олге Миличевић Николић. ${ }^{39}$ Данас се простор парка састоји из три концепцијске целине: свечаног прилаза Скупштини града Београда, уређене површине између дворова са фонтаном у средишту и парковског дела обликованог у слободном стилу. Поред шетачких стаза садржај парка чине дечије игралиште (инж. Бранислав Прошић, 1957), фонтана и базен са бронзаном фигуром „Девојка са крчагом”, спомен-чесма посвећена пионирима (1967), као и бројне уметничке скулптуре: Прекинута игра (Мира Сандић, 1967), Срећа (Иван Саболић, 1985), Споменик Надежди Петровић (Ангелина Гаталица, 1989), Јеж (Миодраг Роган, 1990), обележје Првог светског рата у виду пирамиде од камења у југоисточном углу парка као и споменик Иви Андрићу (Миланко Мандић, 1992) постављен у осовини фонтане у улици Андрићев венац. Посебну вредност парка представља његов биљни фонд, међу којим је и осам стабала са статусом заштићеног природног добра.

\section{Епилог - враћање краљевског знамења}

Послератним реконструкцијама некадашњих дворских здања, разграђивањем и повезивањем дворске баште и простора око Дома Народне скупштине, остварена је идеја о формирању репрезентативног центра државне и престоничке

38 Добровићев предлог уређења предвиђао је задржавање ове зграде; Исто, стр. 12. Етнографски музеј се у овом објекту налазио од 1945. до 1948. године. 3. М. (1954) Етнографски музеј у Београду, Годишњак Музеја града Београда бр. 1, Београд: Музеј града Београда, стр. 320.

39 Đorđević, V. (1980) Još nešto o dvema velikim baštama starog Beograda, Urbanizam Beograda br. 59-60, Beograd: Urbanistički zavod, str. 27-30. 


\section{САША МИХАЈЛОВ и БИЉАНА МИШИЋ}

власти. Иако иницирано потпуно другачијим, пре свега идеолошким разлозима, ово визуелно преиначавање централног градског амбијента прати линију првобитне замисли из времена формирања теразијског комплекса и међуратне идеје о претварању приватне дворске резиденције у јавни простор доступан свима.

Уска повезаност дворског комплекса са историјским и политичким догађајима која га је пратила од самог формирања, још једном је дошла до изражаја крајем прошлог века. Променом политичке климе средином деведесетих година актуелизована је обнова симбола власти на здањима некадашњих дворова. Петокрака са врха куполе Старог двора замењена је 1997. позлаћеном скулптуром двоглавог орла, ${ }^{40}$ некадашњим симболом Краљевине Србије и данас Републике Србије. Рестаурацијом фасада Старог двора 2005. враћени су и оригинални грбови на штитовима грифона на његовој главној фасади. ${ }^{41}$ Истовремено са израдом пројеката рестаурације главне фасаде Старог двора урађен је и пројекат враћања скулптуре двоглавог орла на врх куполе Новог двора, ${ }^{42}$ док је пројектом рестаурације фасада предвиђено враћање хералдичког знамења и на ово дворско здање. ${ }^{43}$

У истом периоду јавиле су се иницијативе да се делу парка, некадашњем дворском врту, врати оригинални изглед који је нестао током измена простора након Другог светског рата. Радовима на реконструкцији изведеним 2004. успостављен је оригиналан изглед врта са водоскоком и цветним партером према улици Краља Милана, ${ }^{44}$ док је након изградње подземне гараже у делу испред Старог двора и овај простор

40 Позлаћена скулптура двоглавог орла рад је академског вајара Мирољуба Стаменковића, аутор пројекта враћања скулптуре је архитекта Зоран Јаковљевић; Dokumentacija ZZSKGB, Projekat postavljanja skulpture dvoglavog orla na obelisk Starog dvora, 1997. godine.

41 Документација З3СКГБ, Пројекат санације и рестаурације главне фасаде и свечане терасе, 2003; Аутори пројекта су архитекте Татјана Виденовић и Зоран Јаковљевић; Пројекат рестаурације фасаде Старог двора оријентисане ка Новом двору, 2004; Пројекат рестаурације фасаде Старог двора, II фаза - фасада оријентисана ка улици Краља Милана, 2006. Аутор пројекта архитекта Татјана Виденовић.

42 Документација З3СКГБ, Пројекат постављања скулптуре двоглавог орла на обелиск Новог двора, 2003. Аутори пројекта су архитекте Татјана Виденовић и Зоран Јаковљевић.

43 Документација З3СКГБ, Пројекат ревитализација фасада Новог двора, 2007-2008. Аутори архитекте Татјана Виденовић и Светлана Марковић.

44 Документација ЈКП „Зеленило-Београд”. Пројекат обнове водоскока и реконструкције зелених површина на простору Старог и Новог двора у Пионирском парку, 2004. Аутори су архитекта Јанко Крстић, Драгутин Алексић и Татјана Урсић. 


\section{САША МИХАЈЛОВ и БИЉАНА МИШИЋ}

партерно уређен цветним орнаментима. ${ }^{45}$ Овим интервенцијама додатно је истакнута репрезентативност најзначајнијих престоничких палата (слика 7).

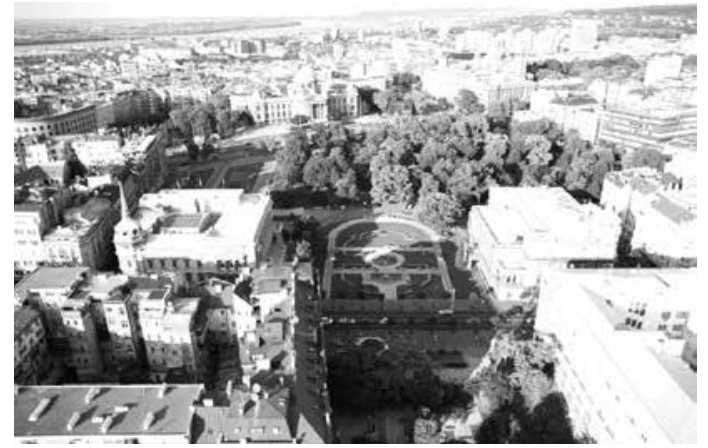

Слика 7 Дворски комплекс и Дом Народне скупштине, 2007. године (Извор: ЗЗСКГБ)

Дворски комплекс на Теразијама је прва плански осмишљена и реализована владарска резиденција у Србији. Захваљујући укључивању најзначајнијих представника српског градитељства, уметности и занатства у њихово пројектовање и обликовање дворски објекти представљају најраскошније грађевине, док њихова целина чини један од најзначајнијих архитектонско-урбанистичких ансамбала у београдском и српском градитељству ${ }^{46}$ Сталним изменама, доградњама и уређењем овог простора током више од стошездесет година његовог постојања, посебно успостављањем складног односа између изграђених структура и њиховог природног и урбаног окружења, стављене су у први план специфичне вредности амбијента засноване на приступачности и доступности јавности. Дворски комплекс на Теразијама као прворазредни показатељ развоја уметничког стваралаштва у Србији, али и одраз политичких и историјских околности у којима је формиран, својом вишезначношћу и визуелном

45 Милановић, Х. (2006) Зеленило Београда, Београд: Зеленило-Београд, стр. 150-163. Аутор уређења партера је Вера Грбић. Током изградње подземне гараже у Пионирском парку приликом археолошких истраживања откривено је 15 римских гробова, четири слободноукопана гроба без могућности датовања и један камени саркофаг. Налазима је потврђено да је овај локалитет део југоисточне некрополе Античког Сингидунума, на којем се сахрањивање обављало током 3. и 4. века наше ере. Током 2011. покретни налази са локалитета Пионирски парк презентовани су у ентеријеру гараже, као прва поставка археолошког материјала у Београду, на месту на коме је откривен. Мићовић, Н. (2011) Археолошки локалитет Пионирски парк, Београд: ЗЗСКГБ.

46 Зграда Старог двора и зграда Новог двора уживају заштиту у складу са Законом о културним добрима од 1983. Пионирски парк је 2007. проглашен за заштићено подручје као споменик природе и категорисан као значајно природно добро. 


\section{САША МИХАЈЛОВ и БИЉАНА МИШИЋ}

репрезентативношћу остварио је снажан допринос и вишеструки утицај на архитектонски, урбанистички и уметнички развој Београда као престонице.

\section{ЛИТЕРАТУРА:}

Аноним (5. VI 1883) Српско-краљевски орао на Краљевом двору, Видело, стр. 3.

Аноним (1. VIII 1904) Рушење Старог дворца, Политика.

Аноним (11. VII 1906) Грађење новог дворца, Штампа.

Аноним (24. VII 1906) Грађење новог дворца, Штампа.

Аноним (6. V 1922), Стари двор, Политика, стр. 3-4.

Аноним (1939) Француска изложба у Музеју кнеза Павла, Уметнички преглед бр. 2, стр. 63.

Аноним (1939) Музеј кнеза Павла - Изложба немачких слика, Уметнички преглед бр. 10.

Борић, Т. И. (2014) Дворови династија Обреновић и Карађорђевић у Србији, докторска дисертација, Филозофски факултет, Универзитет у Београду, Београд.

Громанов албум фотографија 1876-1878, приредио Мијајловић Ж. (2003), Београд, 8. 2. 2016, http://www.ncd.matf.bg.ac.rs/projects/ sr/groman.html

Дамљановић, Т. (1997) Архитекта Светомир Лазић (1894-1985), Саопштељ $а$ бр. 29, Београд: Републички завод за заштиту споменика културе, стр. 244-262.

Димитријевић Марковић, С. (2012) Крсмановићева кућа на Теразијама, Београд: ЗЗСКГБ.

Добровић, Н. (1947) Обнова и изградња Београда - Контуре будућег града, Београд: Урбанистички институт.

Đorđević, V. (1980) Još nešto o dvema velikim baštama starog Beograda, Urbanizam Beograda br. 59-60, Beograd: Urbanistički zavod, str. 27-30.

Ђурић-Замоло, Д. (1991) Стари конак у Београду, Годишњак града Београда бр. 38, Београд: Музеј града Београда, стр. 113-125.

Ђурић-Замоло, Д. (2009) Градитељи Београда 1815-1914, Београд: Музеј града Београда.

Игњатовић, А. Архитектура Новог двора и Музеја кнеза Павла, у: Музеј кнеза Павла, уредила Цветићанин, Т. (2009) Београд: Народни музеј, 58-89.

Ignjatović, A. (2007) Jugoslovenstvo u arhitekturi 1904-1941, Beograd: Građevinska knjiga. 


\section{САША МИХАЈЛОВ и БИЉАНА МИШИЋ}

Јовановић, М. (1988/89) Историзам у уметности XIX века, Caonштењ $а$ бр. 20-21, Београд: Републички завод за заштиту споменика, стр. 275-283.

Кадијевић, А. (1990) Живот и дело архитекте Драгише Брашована 1887-1965, Годишьак града Београда бр. 37, Београд: Музеј града Београда, стр. 141-173.

Кадијевић, А. (1996) Београдски опус архитекте Милана Минића (1889-1961), Годищъак града Београда бр. 43, Београд: Музеј града Београда, стр. 123-152.

Кадијевић, А. (1996) Момир Коруновић, Београд: Републички завод за заштиту споменика културе.

Кадијевић, А. Архитектура и урбанизам у Србији од 1854-1904, у: Наука и техника у Србији друге половине 19. века (1854-1904), уредио Подгорац, Т. (1998) Крагујевац: Универзитет у Крагујевцу, стр. 263-283.

Кадијевић, А. (2005) Естетика архитектуре академизма (XIX-XX века), Београд: Грађевинска књига.

Кадијевић, А. Архитектура - оквир приватног живота у српским земљама од почетка 19. века до Првог светског рата, у: Приватни живот код Срба у деветнаестом веку, уредили Столић, А. и Макуљевић, Н. (2006), Београд: Clio, стр. 245-258.

Кадијевић, А. (2009) Поглед на класицизам у новијој српској архитектури, Рачански зборник бр. 14, Бајина Башта: Фондација Рачанска баштина, Манастир Рача, стр. 115-122.

Кадијевић, А. и Марковић, С. (2003) Милан Минић: архитект и сликар, Пријепоље: Музеј.

Каниц, Ф. (1985) Србија, земља и становништво: од римског доба до краја XIX века, књига 1, Београд: Српска књижевна задруга.

Маневић, 3. (2002-2003) Класицизам у српској архитектури, 3борник Матице српске за класичне студије бр. 4-5, Нови Сад: Матица Српска, стр. 123-127.

Марловић, С. (2005) Трагање за изгубљеном целовитошћу дворског комплекса у Београду, Годишњак града Београда бр. 52, Београд: Музеј града Београда, стр. 195-251.

Мићовић, Н. (2011) Археолошки локалитет Пионирски парк, Београд: ЗЗСКГБ.

Михајлов, С. (2000-2001) Прилог проучавању архитектонског дела Милана Минића у Београду, Годишьак града Београда бр. 47-48, Београд: Музеј града Београда, стр. 225-238.

Михајлов, С. (2013) Зграда Новог двора, Београд: ЗЗСКГБ.

Милановић, Х. (2006) Зеленило Београда, Београд: ЗеленилоБеоград. 


\section{САША МИХАЈЛОВ и БИЉАНА МИШИЋ}

Митровић, К. Двор кнеза Александра Карађорђевића, у: Приватни живот код Срба у деветнаестом веку, уредили Столић, А. и Макуљевић, Н. (2006), Београд: Clio, стр. 302-330.

Мишић, Б. (2005) Ефемерни спектакл - проглашење Србије за краљевину 1882, Наслеђе бр. 6, Београд: ЗЗСКГБ, стр. 85-106.

Мишић, Б. (2013) Зграда Старог двора, Београд: ЗЗСКГБ.

М. К. (1937) Женски портрет, од Тулуз-Лотрека, Уметнички преглед бр. 3.

Несторовић, Б. (2006) Архитектура Србије у XIX веку, Београд: Арт Прес.

Недић, С. В. (1999) Из историје Старог двора, Наслеђе бр. 2, Београд: ЗЗСКГБ, стр. 11-22.

Недић, С. В. (2001) О неким питањима изворне архитектуре Новог двора, Наслеђе бр. 3, Београд: ЗЗСКГБ, стр. 57-66.

Nikić, Lj. (1978) Iz arhitektonske delatnosti Aleksandra Bugarskog u Beogradu, u: Urbanizam Beograda br. 46, Beograd: Urbanistički zavod, str. 64.

Покрајац, М. (2013) Александар Бугарски: пионир академизма у Београду, Годишњак града Београда бр. 60, Београд: Музеј града Београда, стр. 71-108.

Pokrajac, M. (2015) Heraldički dekor u službi vladarske ideologije na fasadama Starog dvora, Artum br. 2, Beograd: Odeljenje za istoriju umetnosti Filozofskog fakulteta u Beogradu, str. 52-61.

Popović, B. (2011) Primenjena umetnost i Beograd 1918-1941, Beograd: Muzej primenjene umetnosti.

Поповић, М. (1997) Хералдички симболи на београдским јавним здањима, Београд: БМГ.

Путник, В. (2012) Прилог проучавању развојних токова међуратне стамбене архитектуре Београда, Наслеђе бр. 13, стр. 153-166.

П. В. (1938) Изложба италијанског портрета, Уметнички преглед бр. 6-7, стр. 221-223.

Ротер-Благојевић, М. (2003) Архитектура грађевина јавних намена изграђених у Београду од 1868. до 1900. године (други део), Архитектура и урбанизам бр. 12-13, Београд: Институт за архитектуру и урбанизам Србије, стр. 73-90.

Стојановић, С. (1912) Српски неимар, Београд.

Столић, А. Приватност у служби репрезентације - двор последњих Обреновића, у: Приватни живот код Срба у деветнаестом веку, уредили Столић, А. и Макуљевић, Н. (2006), Београд: Clio, стр. 331-353.

Тимотијевић, М. (2009) Престоничка урбана меморија и флексибилна национална географија: сађење младице Таковског грма у 


\section{САША МИХАЈЛОВ и БИЉАНА МИШИЋ}

београдском дворском парку, Наслеђе бр. 10, Београд: ЗЗСКГБ, стр. 11-40.

У. (1937) Музеј кнеза Павла: Изложба пољске уметности - откопавања у Стобима, Уметнички преглед бр. 2.

У. (1940) Валонска дворана у Музеју кнеза Павла, Уметнички преглед бр. 1-2.

Васић, П. (1938) Никола Пусен код нас, Уметнички преглед бр. 5, стр. 129-134;

Vujović, B. (1986) Umetnost obnovljene Srbije 1791-1848, Beograd: Prosveta i Republički zavod za zaštitu spomenika kulture.

Вујовић, С. Градско становање и приватност у Србији током 20. века, у: Приватан живот код Срба у двадесетом веку, уредио Ристовић, М. (2007), Београд: Clio, стр. 275-291.

3. М. (1954) Етнографски музеј у Београду, Годишњак Музеја града Београда бр. 1, Београд: Музеј града Београда, стр. 316-321.

\section{Извори:}

\section{Документација ЗЗСКГБ:}

Досијеи споменика културе: Krsmanovićeva kuća na Terazijama, SK-36; Zgrada Starog dvora, SK-159, Zgrada Novog dvora, SK-160;

Konzervatorski uslovi za rekonstrukciju zaštićene zone Andrićevog venaca, KU 16.

Пројекти техничке документације: Projekat postavljanja skulpture dvoglavog orla na obelisk Starog dvora, 1997; Projekat sanacije i restauracije glavne fasade Starog dvora i svečane terase, 2003; Projekat postavljanja skulpture dvoglavog orla na obelisk Novog dvora, 2003; Пројекат рестаурације фасаде Старог двора оријентисане ка Новом двору, 2004; Пројекат рестаурације фасаде Старог двора, II фаза - фасада оријентисана ка улици Краља Милана, 2006; Пројекат ревитализација фасада Новог двора, 2007-2008.

Пројекат обнове водоскока и реконструкције зелених површина на простору Старог и Новог двора у Пионирском парку, ЈКП „Зеленило-Београд”, 2004.

\section{Скраћенице:}

ЗЗСКГБ - Завод за заштиту споменика културе града Београда САНУ - Српска академија наука и уметности

АС - Архив Србије

ЈКП - Јавно комунално предузеће 
САША МИХАЈЛОВ и БИЉАНА МИШИЋ

\author{
Saša Mihajlov and Biljana Mišić \\ Institute for Protection of Cultural Monuments of the City of Belgrade, \\ Belgrade
}

\title{
THE PALACE COMPLEX AT TERAZIJE: FROM A ROYAL RESIDENCE TO A REPRESENTATIVE PUBLIC SPACE
}

\begin{abstract}
The Palace Complex at Terazije was established between midnineteenth century, and the beginning of the third decade of the twentieth century as the first royal residence in Serbia designed and built in accordance with an urban plan. It formed the most important micro ambiance of the central urban zone that started a transition from oriental Belgrade to a modern capital with a European character. The development stages in the formation of the complex, starting from the initial construction of the Simić building (The Old Residence, 184042), through the decoration of the Palace garden and yard, construction of the Little Palace (around 1845), followed by the Palace of the Crown Prince Mihailo (Ministries of Foreign Affairs and the Interior, 1858), and construction of the Old (1881-84) and the New Royal Palace (19111922), indicate complexity of the socio-political circumstances of this period in Serbian history, but also of the development of architectural, stylistic and artistic characteristics of the capital's architecture. Engagement of leading architects, artists, decorators and craftsmen in designing, decoration and furnishing of the edifice and the premises of the palace complex reflects a general picture of the transforming Belgrade's spiritual and cultural climate, through changing its daily life habits, in which the royal residences often served as a model and an initiator of change. Gradually, a complex mosaic was built intertwining the artistic and the political concepts: from the original idea of the architect, Aleksandar Bugarski, for a tripartite composition of the complex, from which only the Old Palace of King Milan Obrenović was realized, to the completing of the complex with the New Palace according to the design of the architect Stojan Titelbah, to converting the New Palace into a museum institution (The Crown Prince Pavle Museum, 1934-1936), and afterwards to reconstructing both structures and the entire area (1947-53) into a seat of new state authorities. Establishing a harmonious relationship between the structures and their natural and urban environment emphasized specific values of the area based on its accessibility and availability.
\end{abstract}

Key words: Terazije, palace, palace gardens, Museum of the Crown Prince Pavle, seat of state authorities, public park 